\title{
Labor's New Opening to International Human Rights Standards
}

\section{Lance Compa}

Most trade unionists were oblivious to international human rights movement in the last half of the twentieth century. For their part, human rights advocates did not include workers' rights on their agenda. But in the late 1990s, labor and human rights advocates came together to reframe workers' collective action as a human rights mission rather than a self-interested syndical action. A new labor-human rights alliance built a wide-ranging discourse of workers' rights as human rights. The expertise and knowledge attributable to human rights actors gave their critique of workers' rights violations in the U.S. a high measure of authoritativeness compared with trade unionists making the same claims. Critics suggest that a human rights frame moves away from a class analysis, de-emphasizing principles of industrial democracy and mass action in favor of individual rights. This article argues that a human rights argument can help win needed labor law reform to protect workers' rights.

\section{Introduction}

Trade unionists and human rights advocates in the U.S. pursued separate agendas in the last half of the twentieth century. Labor leaders focused their demands on recognition from employers, collective bargaining, and a greater share for workers of growing national wealth. Tough organizing and hard bargaining in a strictly domestic legal framework were workers' immediate challenges. Trade unionists had little inclination to learn, invoke, and use international human rights standards to advance their cause.

For its part, the modern human rights movement that emerged from the wreckage of World War II rarely took up labor struggles. Although workers' freedom of association, the right to decent wages, workplace health and safety, and other labor standards are part of the 1948 Universal Declaration of Human Rights and other international human rights instruments, many advocates saw union organizing and collective bargaining as strictly economic endeavors unrelated to human rights.

To be fair, human rights advocates had their hands full with genocide, death squads, political prisoners, repressive dictatorships, and other horrific violations around the world. Compared with these, American workers' problems with organizing and collective bargaining were not human rights priorities. Rights groups' leaders and activists might personally sympathize with workers and trade unions, but they did not see labor advocacy as part of their mission. ${ }^{1}$

The last half of the twentieth century also saw a sharp decline in the proportion of unionrepresented workers in the U.S. The union density rate fell from nearly 40 percent in the 1950 s to 14 percent in 2000. The reasons for this decline are varied. They include structural changes in the economy such as the shift from manufacturing to services, demographic and geographic moves within the U.S. from the Rust Belt to the Sun Belt, job relocation abroad (once called "runaway shops," now more often "outsourcing"), and more. Scholars argue about their relative weight, but there is a general agreement that employers' aggressive interference with workers' organizing rights has significantly affected union density. As one labor scholar noted, "[t]he intensity of opposition to unionization which is exhibited by American employers has no parallel in the western industrial world." ${ }^{2}$ A U.K.-based scholar investigating 
U.S. labor practice says, "[n]o other country in the world has spawned a thriving 'union avoidance' industry, whose mission is to crush workplace organizing campaigns through employer harassment, intimidation, and reprisals." ${ }^{3}$

In the late 1990s, the parallel but separate tracks of the labor movement and the human rights movement began to converge. Trade unionists and human rights advocates started analyzing employers' union busting (not an elegant term, but one that captures the essence of what goes on) as violations of basic rights of association under international human rights standards, not just under U.S. law.

This essay examines the framing and dissemination project that resulted from this new collaboration: how trade union advocates adopted human rights analyses and arguments in their work, how human rights organizations began including workers' rights in their mandates, and the emergence of a new American discourse of workers' rights as human rights. But first, a brief historical review sets the stage.

\section{The Economic Justification for the National Labor Relations Act (NLRA)}

The U.S. labor movement took shape through a sharp class conflict going back to the post-Civil War period. Conflict came to a head in the 1930 s with large-scale organizing campaigns and strikes for union recognition in mass production industries and with the emergence of the new Congress of Industrial Organizations ( $\mathrm{ClO}$ ), the militant alternative to the American Federation of Labor (AFL).

Congress responded to the labor upsurge by passing the NLRA of 1935. The new law granted workers a statutory right to organize and bargain collectively. It compelled employers to bargain with unions chosen by workers in defined "bargaining units." The law also set out and prohibited employers'

"unfair labor practices," including reprisals against union supporters and refusal to bargain with workers' unions.

International human rights were not relevant concepts at that time. But as our coauthor James Pope has demonstrated in his pathbreaking work, Congress conceivably could have grounded the new law in fundamental rights provisions of the Constitution-the First Amendment's protection of speech and assembly, the Thirteenth Amendment's affirmation of free labor, and the Fourteenth Amendment's guarantee of equal protection. ${ }^{4}$ Such a fundamental rights foundation to labor law might have made it easier in our own time to apply international human rights standards to domestic labor law.

As James Pope explained, congressional authors led by New York senator Robert Wagner (the NLRA is also called the Wagner Act) thought that a still-conservative Supreme Court would strike down the Act if they based it on a constitutional rights foundation. Instead, they fixed the law's rationale on the Constitution's Commerce Clause, which gives Congress the power to regulate interstate commerce.

The Act's Section 1 Findings and Policies pointed to "strikes and other forms of industrial strife or unrest, which have the intent or the necessary effect of burdening or obstructing commerce." Section 1 mentions "commerce" thirteen times and contains many other references to the "free flow of goods" and equivalents. There are three references to "rights" of workers. In short, the NLRA was based on the need to remove "burdens on commerce," not on the need to protect workers' fundamental rights.

\section{Employers' Long March}


After passage of the NLRA, employers mounted a long march through courts, new congresses, and new administrations to claw back workers' organizing and bargaining space. Their counterthrust began with an early but little-noticed prize. In the 1938 Mackay Radio decision (304 U.S. 333), the Supreme Court said that employers can permanently replace workers who exercise the right to strike.

Another court-sanctioned counterthrust to union organizing came with the 1941 Virginia Electric Power decision (314 U.S. 469) granting First Amendment protection to employers' antiunion broadsides. Virginia Electric Power set the stage for the conservative 1947 Congress to add a new Section 8 (c) to the NLRA, the so-called "employer free speech" clause insulating employers against any liability for antiunion "views, argument, or opinion, or the dissemination thereof, whether in written, printed, graphic, or visual form ... if such expression contains no threat of reprisal or force or promise of benefit." Since then, employers and consultants who specialize in combating unions have perfected a science of conveying implicit threats through captive-audience meetings, antiunion letters, videos, DVDs, and the like, one-on-one "counseling" by supervisors, and other tactics to break up organizing efforts.

The employer free speech clause only began the antiunion assault in the 1947 amendments known as the Taft-Hartley Act. A new clause called, in a brilliant marketing ploy, "right-to-work" allowed states to prohibit employers and unions from including in their collective bargaining agreement a requirement of dues payments from all represented employees receiving benefits under the contract. More than twenty states have adopted such "right-to-work" laws, which have nothing to do with rights or with work but have much to do with weakening workers' collective bargaining strength. ${ }^{5}$

In other provisions, the Taft-Hartley Act prohibited employees at supplier or customer firms from giving any solidarity support to workers on strike against a "primary" employer. This "secondary boycott" ban means that workers can never countervail employers' support from suppliers and customers continuing business as usual with a primary employer.

The Taft-Hartley Act added supervisors and independent contractors to the list of workers "excluded" from the protection of the NLRA. Excluded workers can be fired with impunity for trying to form unions, or even for expressing sympathetic views toward unions. A 2002 government study found that more than 30 million U.S. workers are excluded from protection of freedom of association rights. ${ }^{6}$

As decades passed, the economic foundation of workers' organizing and bargaining rights became vulnerable to the shifting economic landscape. In the 1930s, the lack of trade union organizing and collective bargaining was defined as a "burden on commerce" justifying the Wagner Act. But by the 1980s, trade unions and collective bargaining had become burdens on a market-driven economy. Without a human rights foundation, workers' freedom of association was vulnerable to market imperatives.

New court decisions reflected the change. In 1981, a time of massive corporate "downsizing" and restructuring, the Supreme Court ruled in the First National Maintenance case (452 U.S. 666) that workers cannot bargain over workplace closures. Instead, employers can refuse to bargain over decisions to close the workplace because their right to entrepreneurial "speed" and "secrecy" outweighs workers' bargaining rights. In a similar vein, the court ruled, in the 1992 Lechmere decision (502 U.S. 527), that workers have no right to receive written information from trade union organizers in a publicly accessible shopping mall parking lot because the employer's private property rights outweigh workers' freedom of association rights. 
In both First National Maintenance and Lechmere, the Supreme Court overruled National Labor Relations Board (NLRB) decisions that favored workers and unions. Doctrinally, courts are supposed to defer to the administrative expertise of the NLRB. In practice, however, federal circuit appeals courts and the Supreme Court often make their own judgment on the merits of a case to overrule the NLRB. Professor Julius Getman has described the dynamic thus:

The courts are notoriously difficult to replace or control. The notion that courts would simultaneously defer and enforce was unrealistic. So long as the courts had the power to refuse enforcement, it was inevitable that they would use this power to require the Board to interpret the NLRA in accordance with their views of desirable policy.... The judicial attitude towards collective bargaining has increasingly become one of suspicion, hostility, and indifference. . . .

The reason for the courts' retreat from collective bargaining is difficult to identify, but it seems to rest on a shift in contemporary judicial thinking about economic issues. The NLRA, when originally passed, had a Keynesian justification. Collective bargaining, it was believed, would increase the wealth of employees, thereby stimulating the economy and reducing the likelihood of depression and recession. Today, courts are more likely to see collective bargaining as an interference with the benevolent working of the market, and, thus, inconsistent with economic efficiency most likely to be achieved by unencumbered management decision making. ${ }^{7}$

In retrospect, setting the NLRA on a commercial foundation rather than on a foundation of fundamental rights was a bargain with the Devil. Perhaps it was strategically necessary at the time to evade a constitutional trap. But in the more than seventy years since passage of the Act, Congress, the courts, and successive administrations and labor boards based their rulings on the Act's economic premises, not on concepts of workers' basic rights. This meant that they made decisions reflecting views about what furthers the free flow of commerce.

The 1935 Congress had seen denial of workers' organizing and bargaining rights as obstructing commerce. Fast-forward to the twenty-first century where legislative, judicial, and administrative rollbacks of workers' rights have brought the opposite view: organizing and collective bargaining are market-distorting and commerce-burdening activities that must yield to employers' property rights and unilateral control of the workplace.

\section{Reframing Workers' Rights as Human Rights}

In the late 1990s, small groups of trade unionists, human rights advocates, and scholar-activists that bridged the two communities began discussing ways to address the decades-long erosion of the NLRA's promise to protect workers' organizing and bargaining rights. They decided to develop a project to rethink and reargue American labor law on a human rights foundation, including what can be learned from international human rights and labor rights principles. 
The core activists who formulated labor's new human rights strategy (and the human rights groups' new labor rights strategy) secured a large grant from the Ford Foundation for a two-year project that resulted in the publication in August 2000 of Human Rights Watch's (HRW) Unfair Advantage: Workers' Freedom of Association in the United States under International Human Rights Standards. Based on voluminous documentary research and extensive field research and interviews with workers, this book-length, 600-footnoted HRW report made a compelling case that the U.S. fails to meet international standards on workers' organizing and bargaining rights.

Unfair Advantage gained significant national and international attention. ${ }^{8}$ Most often cited were these passages:

Workers' freedom of association is under sustained attack in the United States, and the government is often failing its responsibility under international human rights standards to deter such attacks and protect workers' rights. ...

Researching workers' exercise of these rights in different industries, occupations, and regions of the United States to prepare this report, Human Rights Watch found that freedom of association is a right under severe, often buckling pressure when workers in the United States try to exercise it. . . Many workers who try to form and join trade unions to bargain with their employers are spied on, harassed, pressured, threatened, suspended, fired, deported or otherwise victimized in reprisal for their exercise of the right to freedom of association. Private employers are the main agents of abuse. But international human rights law makes governments responsible for protecting vulnerable persons and groups from patterns of abuse by private actors. In the United States, labor law enforcement efforts often fail to deter unlawful conduct. When the law is applied, enervating delays and weak remedies invite continued violations. . . As a result, a culture of near-impunity has taken shape in much of U.S. labor law and practice.

After its initial release and the response it provoked, Unfair Advantage shifted to sustained use as an authoritative reference point in U.S. labor law and human rights discourse. For one thing, the Ford grant sustained a year-long post-publication diffusion project. HRW leaders traveled around the country speaking about the report to local trade unionists and community allies in human rights, civil rights, and other groups, introducing the international human rights analysis to many for the first time.

Unfair Advantage became a standard source for labor advocates reaching out to new constituencies in a language of human rights, not just labor-management relations. For example, Scientific American published a feature on Unfair Advantage for its million-plus readership one year after the report came out. ${ }^{9}$ At its National Convention in June 2002, Americans for Democratic Action (ADA) presented the first annual Reuther-Chavez Award to HRW for its U.S. labor report. $^{10}$

ADA called Unfair Advantage "an exhaustive analysis of the status of workers' freedom to organize, bargain collectively, and strike in the United States, written from the perspective of international human rights standards. It is the first comprehensive assessment of workers' rights to 
freedom of association in the U.S. by a prominent international human rights organization." In presenting the award, ADA noted that "Human Rights Watch, in preparing and releasing Unfair Advantage, has given us what we hope will be enduring evidence in the struggle to regain fair advantage for workers in the U.S." ${ }^{11}$

Unfair Advantage has also become a point of reference in the scholarly community, too. Many U.S. labor law teachers have added the book as a supplemental law school text. So have professors in human rights, political science, sociology, government, industrial relations, and other academic fields. The American Political Science Association (APSA) gave a "best paper" award at its 2001 APSA Annual Meeting to "From the Wagner Act to the Human Rights Watch Report: Labor and Freedom of Expression and Association, 1935-2000." 12

The British Journal of Industrial Relations devoted two issues of a Symposium to the Human Rights Watch report. Symposium editors Sheldon Friedman and Stephen Wood attracted contributions from leading labor law, labor history, and industrial relations scholars in the U.S., Canada, and Britain. In the symposium, University of South Carolina business school professor Hoyt. N. Wheeler said, "[i]t is by explicitly taking a human rights approach that the Human Rights Watch report makes its most important contribution to the understanding and evaluation of American labor policy." University of Texas law school professor Julius Getman called Unfair Advantage "a powerful indictment of the way in which U.S. labor law deals with basic rights of workers."

McMaster University business school professor Roy J. Adams called the publication of Unfair Advantage "an important event because of the new perspective that it brings to bear on American labor policy." University of Essex human rights professor Sheldon Leader termed the report "an important document ... that should help us see what difference it makes to connect up the corpus of principles in labor law with the wider considerations of human rights law." K. D. Ewing, a law professor at King's College, London, said:

In what is perhaps a novel approach for an American study, the report is set in the context of international human rights law ... "where workers are autonomous actors, not objects of unions' or employers' institutional interests" [quoting from the report]. ... The approach of the HRWreport and the methodology that it employs have a universal application; they are particularly relevant for the United Kingdom ... ${ }^{13}$

James Gross concluded:

The report is about moral choices we have made in this country. These moral choices are about, among other things, the rights of workers to associate so they can participate in the workplace decisions that affect their lives, their right not to be discriminated against, and their right to physical security and safe and healthful working conditions. The choices we have made and will make in regard to those matters will determine what kind of a society we want to have and what kind of people we want to be. Human rights talk without action is hypocrisy. This report could be an important first step toward action. ${ }^{14}$ 
In 2005, HRW continued its program on workers' rights in the U.S. with a major report on violations in the U.S. meat and poultry industry. ${ }^{15}$ Blood, Sweat and Fear made these findings on workers' human rights in the meat and poultry industry:

Workers in this industry face more than hard work in tough settings. They contend with conditions, vulnerabilities, and abuses which violate human rights. Employers put workers at predictable risk of serious physical injury even though the means to avoid such injury are known and feasible. They frustrate workers' efforts to obtain compensation for workplace injuries when they occur. They crush workers' self-organizing efforts and rights of association. They exploit the perceived vulnerability of a predominantly immigrant labor force in many of their work sites. These are not occasional lapses by employers paying insufficient attention to modern human resources management policies. These are systematic human rights violations embedded in meat and poultry industry employment....

Health and safety laws and regulations fail to address critical hazards in the meat and poultry industry. Laws and agencies that are supposed to protect workers' freedom of association are instead manipulated by employers to frustrate worker organizing. Federal laws and policies on immigrant workers are a mass of contradictions and incentives to violate their rights. In sum, the United States is failing to meet its obligations under international human rights standards to protect the human rights of meat and poultry industry workers.

In 2007, a massive new report on workplace rights violations of Wal-Mart employees in the U.S. put that company under a human rights spotlight. ${ }^{16}$ In both meatpacking and Wal-Mart, trade unions and activist communities seized on the reports as major resources in their campaigns to reform practices in those industries and companies. The United Food and CommercialWorkers Justice@Smithfield campaign for workers at the Smithfield Foods hog-slaughtering plant in Tar Heel, North Carolina makes extensive use of the HRW report and features it in a campaign video and on its website. Smithfield's violations of workers' rights, including firings, beatings, and false arrests of union supporters, were a central case study in the HRW report.

HRW was the most prominent group to take up workers' rights in the U.S., but it was not alone. Amnesty International USA created a Business and Human Rights division with extensive focus on workers' rights. Oxfam International broadened its development agenda to include labor rights and standards, and its Oxfam America group created a Workers' Rights program to take up these causes inside the U.S. In 2003, Oxfam launched a "national workers' rights campaign" on conditions in the U.S. agricultural sector. In 2004, the group published a major report titled Like Machines in the Fields: Workers without Rights in American Agriculture. ${ }^{17}$

\section{The Labor Side}

On the union side, labor advocates introduced new human rights initiatives. The AFL-CIO has launched a broad-based "Voice@ Work" project, which it characterizes as a "campaign to help U.S. 
workers regain the basic human right to form unions to improve their lives." Voice@Work stresses international human rights in workers' organizing campaigns around the country. In 2005, the labor federation held more than 100 demonstrations in cities throughout the U.S. and enlisted signatures from eleven Nobel Peace Prize winners, including the Dalai Lama, Lech Walesa, Jimmy Carter, and Archbishop Desmond Tutu of South Africa, supporting workers' human rights in full-page advertisements in national newspapers. ${ }^{18}$

In December 2006, the AFL-CIO marked International Human Rights Day with a two-day Strategic Organizing Summit meeting for trade union organizers. Materials to participants declared that "International Human Rights Day is the anniversary of the ratification of the United Nations Universal Declaration of Human Rights, which recognizes as a basic human right the freedom of all workers to form unions and bargain together." The conference launched a campaign for passage of the Employee Free Choice Act (EFCA) in the Congress following Democratic gains in the 2006 midterm elections.

The EFCA would incorporate international labor rights principles into U.S. law on union organizing. ${ }^{19}$ A key Senate sponsor said, "[t]he right to organize and join a union is a fundamental right recognized in the United Nations Declaration of Human Rights. Yet, the United States violates this fundamental principle every day because our current laws don't adequately protect employee rights. ${ }^{20}$

In 2004, trade unions and allied labor support groups created a new nongovernmental organization (NGO) called American Rights at Work (ARAW). ARAW launched an ambitious program to make human rights the centerpiece of a new civil society movement for U.S. workers' organizing and bargaining rights. ARAW's twenty-member board of directors includes prominent civil rights leaders, former elected officials, environmentalists, religious leaders, business leaders, writers, scholars, an actor, and one labor leader (AFL-CIO president John Sweeney). The group's "International Advisor" is Mary Robinson, former United Nations High Commissioner for Human Rights. ${ }^{21}$

Less directly connected to organized labor but with rights at work an important part of its agenda, the National Social and Economic Rights Initiative (NESRI) took shape the same year with the express mission of incorporating principles of the UN Covenant on Economic, Social, and Cultural rights into U.S. law and practice. NESRI is devoted to "working with organizers, policy advocates and legal organizations to incorporate a human rights perspective into their work and build human rights advocacy models tailored for the U.S." 22

Along with NESRI, the Robert F. Kennedy Memorial Center for Human Rights has helped the Coalition of Immokalee Workers in campaigns stressing human rights for agricultural workers in Florida. The coalition's efforts brought a series of successful slavery prosecutions against labor traffickers in the state and won improvements in wages and working conditions for fieldworkers in a sustained campaign against Taco Bell and its parent, Yum Brands, Inc. ${ }^{23}$ In general, many organizations are turning to international human rights arguments in defense of immigrant workers in the U.S. ${ }^{24}$

The National Employment Law Project (NELP) includes an immigrant worker project under the rubric "workers rights are human rights-advancing the human rights of immigrant workers in the United States." NELP has been a leader in filing complaints on immigrant workers' rights violations in the U.S. to the Inter-American Commission and Inter-American Court of Human Rights. ${ }^{25}$

The National Workrights Institute (NWI) was founded in 2000 by the former staff of the American Civil Liberties Union's National Taskforce on Civil Liberties in the Workplace. The NWI describes itself as "a new organization dedicated to human rights in the workplace," with a declared 
strategy of selecting "a small number of issues where there is both the potential of creating substantial long range improvement in workplace human rights and a current opportunity for constructive engagement." The group focuses on electronic monitoring in the workplace, drug testing, genetic discrimination, lifestyle discrimination, and law and practice on wrongful discharge. ${ }^{26}$

Reaching out to the religious community, Interfaith Worker Justice (IWJ) is a national coalition of leaders of all faiths framing workers' rights under religious principles. The IWJ places divinity students, rabbinical students, seminarians, novices, and others studying for careers in religious service in union organizing internships. Through a national network of local religious coalitions, it also sponsors projects for immigrant workers, poultry workers, home-care workers, and other low-wage employees. The IWJ gives special help when religious based employers such as hospitals and schools violate workers' organizing and bargaining rights. $^{27}$

A new student movement that began against sweatshops in overseas factories has adopted a human rights and labor rights approach to problems of workers in their own campuses and communities, often citing human rights as a central theme. Students at many universities held rallies, hunger strikes, and occupations of administration offices to support union organizing, "living wage," and other campaigns among blue-collar workers, clerical and technical employees, and other sectors of the university workforce. ${ }^{28}$

This section could be amplified with yet more examples of new organizations, or new projects within long-established groups, taking up U.S. workers' rights as human rights. The point here is to affirm that the human rights and labor communities no longer run on separate, parallel, never-meeting tracks. They have joined in a common mission gaining traction to advance workers' rights, and human rights discourse has become an integral part of labor advocacy.

\section{Trade Union Human Rights Reports}

The new human rights mission in the labor movement is reflected in the use unions are making of human rights reports in specific organizing campaigns. Trade unionists find that charging employers with violations of international human rights, not just violations of the NLRA, throws companies on the defensive and gives more force to their appeals to the court of public opinion. Employer conduct that is entirely legal under U.S. law-captive audience meetings, one-on-one supervisor pressure, threats of permanent replacement, and much more-is vulnerable to attack in light of International Labor Organization (ILO) standards and international human rights norms.

\section{Maersk}

The Teamsters union launched a human rights campaign against Maersk-Sealand, the giant Denmark-based international shipping company, for violating rights of association among truck drivers who carry cargo containers from ports to inland distribution centers. The company fired workers who protest low pay and dangerous conditions, and threatened retaliation against others if they continue their organizing effort. A human rights analysis and critique of the company's actions issued by the Teamsters in 2004 said: 
The responsibility of multinational corporations to recognize international human rights is becoming an important facet of international law. . . A review and analysis of recent actions by Maersk's U.S. divisions reveal a systematic pattern of reprisals against owner-drivers who seek to exercise basic rights of association....

The report went on to present detailed case studies of Maersk's labor rights violations. It concluded:

Maersk officials claim that as independent contractors, not employees, their drivers are not covered by the National Labor Relations Act and can be dismissed for union activity with impunity. The company also maintains that drivers are also subject to antitrust laws and can be threatened with lawsuits for violations.

But the often artificial distinction between employees and contractors is irrelevant to a human rights analysis. The Universal Declaration of Human Rights says everyone has the right to freedom of association and the right to form trade unions. UN covenants and ILO conventions and declarations on freedom of association apply to all workers, not some workers.

Among the report's recom mendations were these on hum an rights:

Maersk and its U.S. divisions should undertake internal training programs for managers on international human rights and labor rights norms affecting workers. ... Maersk should declare publicly its commitment to respect international human rights and labor rights standards, including a policy of nonreprisals against any workers who exercise rights of assembly, association and speech in connection with their employment. ...

Failing the implementation of these recommendations, the International Brotherhood of Teamsters and the International Transport Federation should consider filing complaints in one or more international human rights and labor rights venues, such as the International Labor Organization's Committee on Freedom of Association or the NAFTA Labor Commission; under the OECD's Guidelines for Multinational Enterprises, or with the European Court of Justice. $^{29}$

This was not just a report that sat on shelves. The union printed thousands of copies for distribution to affiliates of the International Transport Federation, the global trade union for workers in the transport sector. In 2004, workers protested at the Danish embassy and at consulates around the U.S., distributing copies of the report. ${ }^{30}$ In 2005, union leaders went to the corporation's annual shareholders meeting in Copenhagen, giving copies to investors and to the Danish media, with significant attention. ${ }^{31}$ In 2006 , 
the union introduced a shareholders resolution, common at American companies' annual meetings but a novelty for Maersk, calling on the company to adopt international labor rights standards as official company policy. ${ }^{32}$

\section{Resurrection Health}

Similar violations by a large Catholic hospital chain in Chicago prompted a human rights report by the American Federation of State, County \& Municipal Employees (AFSCME) on how the employer's actions violated both international human rights standards and principles of Catholic social doctrine. This report said:

The actions of RHC management demonstrate a systematic pattern of interference with workers' organizing rights and reflect a failure to meet human rights principles and obligations. ... Management signals a fundamental misunderstanding of the nature of the rights at stake when it says that it respects "the right of unions to represent employees if employees so choose." This mistakenly defines "the right of unions" as the right in question, rather than the right of workers to freely form and join unions and to bargain collectively, which is the core international human rights standard.

Focusing on union rights rather than worker rights is management's basis for launching an aggressive campaign of interference against RHC workers' organizing efforts. Management asserts that it is battling the union, not battling its own employees. However, workers are the ones who suffer management harassment, intimidation, spying, threats and other violations of rights recognized under international human rights law. ... ${ }^{33}$

This report too served as a tool for union organizing in the workplace and for organizing support in local political, religious, and human rights communities. ${ }^{34}$

\section{First Student}

The Teamsters union and the Service Employees International Union collaborated to present a human rights report at the May 2006 annual general meeting of First Group PLC, a multinational British firm. The report detailed workers rights violations by its U.S. subsidiary, First Student, Inc., a school bus transportation company with a record of aggressive interference with workers' organizing efforts. Rather than quote from the report, this excerpt from a related news article reflects its use:

The head of Britain's biggest transport company promised yesterday to "stamp out anti-union behaviour" by senior managers at a key US subsidiary amid unrest among the organisation's shareholders.

Martin Gilbert, the chairman of First Group, told the company's annual meeting the organisation was taking the issue "very seriously" after a number of 
institutional shareholders voted for a "human rights" motion in defiance of the board's wishes.

First Student, which operates more than 20,000 yellow school buses in the US, has been accused of harassing and intimidating union activists. ...

The group launched an investigation into the allegations of anti-union behaviour and will report back to shareholders in the autumn.

Outside the meeting, members of the Transport \& GeneralWorkers' Union handed out copies of a report on First Student's labour relations policies concluding that First-Student violated international human rights standards on workers' freedom of association.

A spokesman for First said the group was not anti-union and "never had been." The board believed its present code of ethics covered the points made in the motion which called for the company to abide by standards laid down by the UN's International Labour Organisation. However, directors would consider whether policies should be brought more in line with ILO principles.

The group would ensure there were formal training programmes in place for U.S. managers to ensure they abided by group policies. ${ }^{35}$

\section{Using International Instruments}

The American labor movement's new interest in international human rights law is also reflected in its increasing use of ILO complaints charging violation of conventions 87 and 98 on freedom of association, the right to organize, and the right to bargain collectively. While recognizing that the ILO Committee on Freedom of Association (CFA) cannot "enforce" its decisions against national labor law authorities and courts, U.S. unions are turning to the committee for its authoritative voice and moral standing in the international community. They believe that committee decisions critical of U.S. violations of workers' organizing and bargaining rights can bolster movements for legislative reform to reverse antilabor decisions by the NLRB and the courts.

\section{Hoffman Plastic Case}

In 2002, the AFL-ClO filed a CFA complaint against the Supreme Court's Hoffman Plastic decision. The Supreme Court's 5-4 ruling held that an undocumented worker, because of his immigration status, was not entitled to back pay for lost wages after he was illegally fired for union organizing. The fivejustice majority said that enforcing immigration law takes precedence over enforcing labor law.

The four dissenting justices said there was not such a conflict and that a "backpay order will not interfere with the implementation of immigration policy. Rather, it reasonably helps to deter unlawful activity that both labor laws and immigration laws seek to prevent."

The union federations' ILO complaint said:

The Hoffman decision and the continuing failure of the U. S. administration and Congress to enact legislation to correct such discrimination puts the United 
States squarely in violation of its obligations under ILO Conventions 87 and 98 and its obligations under the ILO's 1998 Declaration on Fundamental Principles and Rights at Work. From a human rights and labor rights perspective, workers' immigration status does not diminish or condition their status as workers holding fundamental rights. ... .

By eliminating the back pay remedy for undocumented workers, the Hoffman decision annuls protection of their right to organize. The decision grants license to employers to violate workers' freedom of association with impunity. Workers have no recourse and no remedy when their rights are violated. This is a clear breach of the requirement in Convention 87 to provide adequate protection against acts of anti-union discrimination. ${ }^{36}$

In November 2003, the CFA issued a decision that the Hoffman doctrine violates international legal obligations to protect workers' organizing rights. The committee concluded that "the remedial measures left to the NLRB in cases of illegal dismissals of undocumented workers are inadequate to ensure effective protection against acts of anti-union discrimination." ${ }^{37}$

The ILO committee recommended congressional action to bring U.S. law "into conformity with freedom of association principles, in full consultation with the social partners concerned, with the aim of ensuring effective protection for all workers against acts of anti-union discrimination in the wake of the Hoffman decision."

\section{Supervisory Exclusion Case}

In October 2006, the AFL-CIO filed a CFA complaint against the NLRB decision in the so-called Oakwood Trilogy, in which the NLRB announced an expanded interpretation of the definition of "supervisor" under the NLRA. ${ }^{38}$ Under the new ruling, employers can classify as "supervisors" employees with incidental oversight over coworkers even when such oversight is far short of genuine managerial or supervisory authority.

In its complaint to the ILO, the AFL-CIO cited Convention No. 87's affirmation that "[w]orkers and employers, without distinction whatsoever, shall have the right to establish and ... to join organizations of their own choosing without previous authorization. The federation argued that "[i]n violation of the Convention, the NLRB's Oakwood trilogy creates a new distinction in U.S. labor law denying freedom of association to employees deemed 'supervisors' under the new test for supervisory status."

In connection with Convention No. 98's requirement that "[w]orkers shall enjoy adequate protection against acts of anti-union discrimination," the AFL-CIO asserted that the NLRB's Oakwood trilogy 'strips employees in the new 'supervisor' status of any and all protection. Employers may fire them with impunity if they do not relinquish union membership or if they participate in union activities. Employers can even force these employees, under pain of dismissal, to participate in management's anti-union campaigns."

The AFL-ClO complaint pointed to principles established by earlier CFA cases from other countries involving the status of workers deemed "supervisors" ${ }^{39}$ : 
- The expression "supervisors" should be limited to cover only those persons who genuinely represent the interests of employers.

- Legal definitions of "supervisors" or other excluded categories of workers should not allow an expansive interpretation that excludes large numbers of workers from organizing and bargaining rights.

- Employees should not be "excluded" to undermine worker organizing or to weaken the bargaining strength of trade unions.

- Changing employees' status to undermine the membership of workers' trade unions is contrary to the principle of freedom of association.

- Even true supervisors have the right to form and join trade unions and to bargain collectively, although the law may require that their bargaining units be separate from those of supervised employees.

The AFL-CIO called on the committee to "lend its voice and its moral standing to support workers' freedom of association in the United States" and concluded:

Finally, we ask the Committee to send a direct contacts mission to the United States to examine the effects of the NLRB's Oakwood trilogy. Such direct contact with workers, union representatives, employers and their representatives, and labor law authorities will provide the Committee with "on the ground" understanding of the issues. Direct contacts will better inform the Committee's analysis by giving life to its review of documents in the case. A direct contact mission will have the added benefit of bringing dramatic public attention to the work of the Committee on Freedom of Association in a country and a labor law community that, lamentably, know little about the ILO and the authoritative role of the Committee on Freedom of Association.

\section{North Carolina Public Employees Case}

The United Electrical, Radio and Machine Workers of America (UE) is an independent union known for its progressive politics and internal democracy. Traditionally a manufacturing sector union, the UE began an innovative organizing campaign among low-paid public sector workers in North Carolina, a state that prohibits collective bargaining by public employees. Using state and local civil service procedures, the union has won several grievances and wage increases for workers.

In 2006, the UE convinced the International Commission for Labor Rights (ICLR), a new NGO composed of labor lawyers and professors from around the world, to hold a public hearing in North Carolina to hear firsthand from union supporters about violations of their organizing and bargaining rights. Labor experts from Canada, Mexico, Nigeria, India, and South Africa joined the hearing. The ICLR issued a report finding "significant violations of internationally recognized labor standards in the public sector in North Carolina, which were strongly correlated to the absence of collective bargaining rights. ${ }^{40}$ 
In 2006, the UE filed a complaint with the ILO CFA, charging that North Carolina's ban on public worker bargaining and the failure of the U.S. to take steps to protect workers' bargaining rights violate Convention No. 87's principle that "all workers, without distinction" should enjoy organizing and bargaining rights, and Convention No. 98's rule that only public employees who are high-level policymakers, not rank-and-file workers, should have the right to bargain. In April 2007, the committee ruled in the union's favor, saying:

In conclusion, the Committee emphasizes that the right to bargain freely with employers, including the government in its quality of employer, with respect to conditions of work of public employees who are not engaged in the administration of the State, constitutes an essential element in freedom of association, and trade unions should have the right, through collective bargaining or other lawful means, to seek to improve the living and working conditions of those whom the trade unions represent. The public authorities should refrain from any interference which would restrict this right or impede the lawful exercise thereof. Any such interference would appear to infringe the principle that employers' and workers' organizations should have the right to organize their activities and to formulate their programmes....

The Committee requests the [United States] Government to promote the establishment of a collective bargaining framework in the public sector in North Carolina-with the participation of representatives of the state and local administration and public employees' trade unions, and the technical assistance of the [ILO] Office if so desired-and to take steps aimed at bringing the state legislation, in particular through the repeal of NCGS §95-98 [the statute prohibiting collective bargaining by public employees], into conformity with the freedom of association principles, thus ensuring the effective recognition of the right of collective bargaining throughout the country's territory. The Committee requests to be kept informed of developments in this respect. $^{41}$

Alongside the ILO complaint, the UE turned to the Inter-American Commission for Human Rights (IACHR) with a request for a "thematic hearing" under IACHR procedures on the conflict between North Carolina's prohibition on collective bargaining and freedom of association protections in the American Declaration of the Rights and Duties of Man, the American Convention on Human Rights, and the InterAmerican Democratic Charter. ${ }^{42}$

\section{The AFL-CIO's "Mega-Complaint"}

In October 2007, the AFL-CIO filed a "mega-complaint" to the ILO CFA, arguing that the cumulative effect of NLRB decisions under the Bush administration has put the entire labor law system outside the bounds of ILO principles. The complaint pointed to dozens of NLRB decisions in recent years that diminished workers' organizing rights and expanded management's antiunion arsenal. Especially 
telling were the 2007 "September Massacre" cases in which the board issued a myriad of long-delayed decisions on key issues, resolving them all in management's favor. ${ }^{43}$

As these cases and complaints suggest, the readiness of workers' rights advocates to use international labor instruments and mechanisms has expanded exponentially in the past ten years. Some unions are now laying the ground for a next stage: using trade agreements to file complaints against the U.S. for workers' rights violations under labor rights clauses in trade agreements. Especially damaging, and featured in the AFL-CIO complaint, was the Dana decision allowing antiunion groups like the National Right-to-Work Committee to foment dissidence among a minority of employees against majority decisions to organize under a "card-check agreement" between a union and an employer. Under Dana, minority groups can nullify the employer's recognition of the union as the majorityselected bargaining agent and halt bargaining altogether, throwing the process back into the delayridden NLRB election process. ${ }^{44}$

\section{A Progressive Critique of the Human Rights Frame}

Some labor supporters caution against too much emphasis on a human rights argument for workers' organizing in the U.S. They maintain that a rights-based approach fosters individualism instead of collective worker power; that demands for "workers' rights as human rights" interfere with calls for renewed industrial democracy; that channeling workers' activism through a legalistic rights-enhancing regime stifles militancy and direct action. Labor historian Joseph McCartin says:

Because it puts freedom ahead of democracy, rights talk tends to foster a libertarian dialogue, where capital's liberty of movement and employers' "rights to manage" are tacitly affirmed rather than challenged. Arguing in a rightsoriented framework forces workers to demand no more than that their rights be respected alongside their employers' rights. ...

I am not suggesting that today's labor advocates should abandon their rightsbased arguments. These have undeniable power, speak to basic truths, and connect to important traditions-including labor's historic internationalism. Rather, I am arguing that the "workers' rights are human rights" formulation alone will prove inadequate to the task of rebuilding workers' organizations in the United States unless we couple it with an equally passionate call for democracy in our workplaces, economy, and politics. ${ }^{45}$

Historian Nelson Lichtenstein argues:

Two years ago HRW published Unfair Advantage: Workers' Freedom of Association in the United States Under Human Rights Standards, which is certainly one of the most devastating accounts of the hypocrisy and injustice under which trade unionists labor in one portion of North America. ... .

This new sensitivity to global human rights is undoubtedly a good thing for the cause of trade unionism, rights at work, and the democratic impulse. 
... [But] as deployed in American law and political culture, a discourse of rights has also subverted the very idea, and the institutional expression, of union solidarity. ... Thus, in recent decades, employer anti-unionism has become increasingly oriented toward the ostensible protection of the individual rights of workers as against undemocratic unions and restrictive contracts that hamper the free choice of employees ... without a bold and society-shaping political and social program, human rights can devolve into something approximating libertarian individualism. ${ }^{46}$

Historian David Brody suggests that a human rights analysis too willingly accepts the view that collective bargaining is gained through a bureaucratic process of government certification rather than through workers' direct action. "That a formally democratic process might be at odds with workers' freedom of association," he writes, "seems to fall below the screen of "human rights analysis." ${ }^{47}$

\section{A Net Positive Effect}

These are healthy cautions from serious, committed scholars and defenders of trade unions and workers' rights. They contribute to a needed debate about the role and effectiveness of human rights activism and human rights arguments in support of workers' rights. All three historians agree that human rights advocacy is important for advancing the cause of social justice; that one need not make an "either-or" choice.

I argue here that conditions have ripened for raising the human rights platform to advance workers' rights in the U.S. International labor law developments are fostering new ways of thinking and talking about labor law in the U.S.- - a necessary condition for changing policy and practice.

In this new framework, human rights experts bring authoritativeness to labor discourse that trade unionists can never achieve. If HRW's Unfair Advantage had been published by the AFL-CIO, it would have been dismissed as a self-interested partisanship. If it had been published by an academic press written (as it was) by a researcher who had worked for many years as a union organizer and negotiator, it would have been discounted as a biased study by a pro-union partisan. But coming from HRW, the report carried unmatchable authority in light of HRW's independence and expertise in the human rights arena.

The human rights frame gives new force to trade union organizing and bargaining campaigns. Here are some ways how:

- Arguing from a human rights base, labor advocates can identify violations, name violators, demand remedies, and specify recommendations for change in ways not available within the framework of U.S. labor law.

- Workers are empowered in organizing and bargaining campaigns when they are themselves convinced-and convincing the public-that they are vindicating their fundamental human rights, not just seeking a wage increase or more job benefits.

- Employers are driven into a corner by charges that they are violating workers' human rights.

- The larger society is more responsive to the notion of trade union organizing as an exercise of human rights rather than economic strength. 
- An international human rights foundation strengthens international strategic campaigns because counterparts in trade unions and allied groups abroad are more knowledgeable about and more responsive to solidarity appeals based on ILO standards and human rights concerns.

A human rights emphasis also has alliance-building effects. Human rights organizations and their supporters are a major force in civil society that historically stood apart from labor struggles. Now the human rights community is committed to promoting workers' rights. Using the human rights frame, labor advocates have found new entries into religious, civil rights, and other allies. The human rights frame has also been key to reaching trade unionists and allied labor supporters abroad, who often are more knowledgeable about and responsive to human rights claims. We cannot foresee in detail how these new alliances will proceed. But the human rights argument has surely succeeded in reframing the debate, redefining the problems, and reshaping solutions to protect workers' rights as human rights in the U.S.

Some advances can already be discerned. Under pressure from the international human rights campaign, Maersk has ended its reprisals against union supporters and is engaged in sustained talks with the Teamsters union to find a collective bargaining solution for port truck drivers. Prompted by its UK parent company responding to human rights criticisms, First Student, Inc. has retreated from its worst forms of antiunion campaigning. Thanks to management's reduced role, workers have won a series of NLRB elections in the past year, bringing thousands of new workers into the union.

The EFCA passed the House of Representatives in March 2007 and secured a majority in the Senate, where it was stymied by a Republican filibuster. President Bush would have vetoed it anyway, but the public education campaign set the stage for a renewed push after the 2008 elections.

In North Carolina, sympathetic state legislators responded to the ILO's decision by introducing legislation allowing public sector workers to bargain collectively. Success is a longer-term process, to be sure, but the ILO case launched a debate in that state that had been stilled for decades.

This is not meant to overstate the case for human rights or to exaggerate the effects of the human rights argument. Labor advocates cannot just cry "human rights, human rights" and expect employers to change their behavior or Congress to enact labor law reform. In the EFCA debate, strategists concluded that human rights would be a secondary frame, yielding priority to a "restore the middle class" argument: that making it easier for workers to organize and bargain would address growing economic inequality.

Change will be incremental. Labor and human rights advocates still confront general unawareness in the U.S. of international human rights standards and of the ILO's work in giving precise meaning to those standards. Advocates still have an enormous educational challenge of making them more widely known and respected. Trade unions' use of international instruments and mechanisms and human rights groups' labor rights initiatives contribute to this educational effort. At the same time, they change the climate for workers' organizing and bargaining by framing them as a human rights mission, not as a test of economic power between institutional adversaries.

\section{Getting It Right: The Politics of Labor Reform}


The new labor-human rights alliance can help restore the purpose of the Wagner Act. Senator Wagner and his team got it right in the original NLRA with expansive Section 7 rights and a strong definition of unfair labor practices in Section 8. The original board got it right, too, with certification based on cards and strict scrutiny of employers' antiunion statements.

The NLRA is supposed to vindicate workers' freedom of association by coercing unwilling employers into a collective bargaining relationship. As most employers in the U.S. are unwilling to bargain voluntarily, that is what the law should do: bring the power of the state to force employers to bargain with organized employees exercising rights of association.

The NLRA and its enforcement mechanism have failed to live up to the law's promise. The failures can be ticked off in labor law shorthand: Mackay, First National Maintenance, Lechmere, Kentucky River and Oakwood, Hoffman Plastic, Dana, and other landmark cases. ${ }^{48}$ Not to mention the Taft-Hartley Act. But these are reasons to correct the failures through new legislation and increased staffing and funding for enforcement. This means political struggle by workers, unions, and their allies to win a White House, a House of Representatives, and a filibuster-proof Senate to accomplish these goals.

Employers and their allies knew what they wanted in the Taft-Hartley Act: "Right-to-Work"; "Employer Free Speech"; independent contractor and supervisor exclusions; union unfair labor practices; a ban on secondary boycotts backed up by mandatory injunctions and heavy financial penalties. Then they went out and got the Congress to give it to them. A veto-proof Congress, no less (President Truman vetoed the Taft-Hartley Act, and Congress overrode the veto).

Workers and trade unions and their allies now face the same challenge. First, they must define and frame the goals: immediate reinstatement of workers fired for organizing; organizers' access to the workplace; organizing by majority sign-up; first contract arbitration; a ban on striker replacements; coverage for dependent contractors and low-level supervisors, an end to "employer free speech" loopholes.

But the real prize is to build a political movement to achieve these goals. The EFCA is a start. Advocates have to do the hard job of framing the issues, educating the public, educating legislators, and mobilizing workers to win a government that will act on Employee Free Choice and other goals.

\section{Conclusion}

Workers want the law on their side. This does not sit well with advocates who see the law as an oppressive, militancy-busting shackle that workers should blow off in favor of direct syndical combat against employers. However, the balance of power in the U.S. economy is such that jettisoning the law and having workers engage in a test of sheer force with employers would be suicidal. The labor movement still must seek the protective shield of strong labor laws, strongly enforced by federal power. An allied human rights movement can help achieve this goal.

The Wagner Act recognized a basic fact about a capitalist economy: employers inherently hold the upper hand in the workplace based on property ownership, entrepreneurial control, and management authority. Accordingly, the law must side with workers to right the balance. Federal labor law and labor law authorities should be forthrightly pro-worker, pro-union, and pro-collective bargaining. Winning even modest legislative victories in this direction will give workers confidence that the law is on their side. In turn, success on the political front will generate new organizing success. 
I understand that the Wagner Act did not itself liberate workers to begin organizing in the 1930s. Rather, workers' massive strikes and organizing movements in the 1930s helped win an administration and a Congress that adopted the law. The Wagner Act and the Supreme Court's decision to uphold it in the Jones \& Laughlin Steel case ${ }^{49}$ actually ratified freedoms that millions of American workers had already claimed in shops, mines, mills, and streets around the country.

Progressive members of Congress voted for the NLRA out of conviction, but many others, and probably President Roosevelt and the Supreme Court majority, were moved more by fear of uncontrolled industrial strife. Strikes and sit-downs in San Francisco, Minneapolis, Akron, Toledo, Flint, and other places meant that employers could not go to sleep at night certain that their workers would show up to their jobs in the morning or, if they did, that they would do any work. For most in Congress and the courts, the purpose of the Wagner Act was to restore stability to a shaken system of labor relations.

But this is not cause to scorn the NLRA as an unnecessary and counterproductive sop to workers. The Act's passage and Supreme Court approval electrified working people and their allies, emboldening them with the feeling that the weight of the federal government was on their side. A lot more organizing success came after the passage and enforcement of the NLRA than before it. The Act spurred the largescale organizing drives of the $\mathrm{ClO}$, and tough enforcement by the early NLRB overcame resistance among such holdout employers as Ford, Westinghouse, and Little Steel.

Lance Compa is a senior lecturer at Cornell University's School of Industrial and Labor Relations in Ithaca, New York, where he teaches U.S. labor law and international labor rights. Address correspondence to Lance Compa, Cornell University, ILR School Dept. of Collective Bargaining, Labor Law \& Labor History, 333 Ives East, Ithaca, NY 14853-3901, Telephone: 011 (607) 255-7314; Facsimile: 011 (607) 255-6840. E-mail: lac24@cornell.edu

\section{Notes}

\footnotetext{
${ }^{1}$ For a fuller discussion of the failure of labor and human rights activists to see each other's work as part of their own, see Virginia A. Leary, "The Paradox of Workers' Rights as Human Rights," in Human Rights, Labor Rights, and International Trade, ed. Lance A. Compa and Stephen F. Diamond (University of Pennsylvania Press, 2003).

${ }^{2}$ See Theodore St. Antoine, "Federal Regulation of theWorkplace in the Next Half Century," 61 Chicago-Kent Law Review 631 (1985).

${ }^{3}$ See John Logan, "The Union Avoidance Industry in the United States," 44 British Journal of Industrial Relations 651 (2006).

${ }^{4}$ See James Gray Pope, "The Thirteenth Amendment Versus the Commerce Clause: Labor and the Shaping of American Constitutional Law, 1921-1957," 102 Columbia Law Review 1 (2002). Professor Pope suggests that the Supreme Court was really responding to massive social pressures of workers' organizing and strikes, including sit-down strikes, and that "there is no a priori reason to believe that-had the justices been presented with an argument based on the Thirteenth Amendment instead of the Commerce Clause-they would not have chosen to uphold the Act on that ground."

${ }^{5}$ Workers in right-to-work states earn on average $\$ 7,000$ a year less than workers in states where employers and unions can agree to "union security" clauses. See Center for Policy Alternatives, "Right to work for less," Policy Brief, at http://www.stateaction.org/issues/issue.cfm/issue/RightToWorkForLess.xml.
} 
${ }^{6}$ See U.S. General Accounting Office, Collective Bargaining Rights: Information on the Number of Workers with and without Bargaining Rights, GAO-02-835 (September 2002).

${ }^{7}$ See Julius Getman, “The National Labor Relations Act: What Went Wrong; Can We Fix It?" 45 Boston College Law Review 125 (December 2003). He wrote before the Bush administration's new 3-2 board majority became a mindless rubber stamp for employers' briefs, so that conservative judges (i.e., most judges) can now happily invoke the deferral doctrine to leave the board's anti-worker decisions undisturbed.

${ }^{8}$ See, for example, Julian Borger, "Workers' Rights 'Abused in US,' " The Guardian (London), August 30, 2000, at 12; Ned Glascock, "Rights Group Targets Firms," Raleigh News \& Observer, August 31, 2000, at A3; "Study: Labor Law Fails Millions," (editorial) New York Daily News, August 31, 2000, at 84; “Labor Day Finds Some with Old Troubles," (editorial), Greensboro News \& Record, September 4, 2000, at A8, Robert McNatt, "The List: Union Busters," Business Week, September 11, 2000, at 14; Steven Greenhouse, "Report Faults Laws for Slowing Growth of Unions," The New York Times, October 24, 2000, at A20; Lance Compa, "U.S. Workers' Rights Are Being Abused," (Op-Ed) The Washington Post, October 30, 2000, at A27; "O governo dos EUA tem sido ineficiente na defesa dos trabalhadores," O Estado de Sao Paulo, November 1, 2000; Roy Adams, "U.S. Immigrants Being Exploited," The Hamilton Spectator, November 21, 2000, at D10; Arvind Panagariya, "Shoes on the Other Foot: Stunning Indictment of Laws Governing Workers' Rights in the United States," The Economic Times (India), December 20, 2000, at 1; "Worker Rights," Scripps Howard News Service, February 21, 2001.

${ }^{9}$ See Rodger Doyle, "U.S. Workers and the Law," Scientific American, August 2001, at 24.

${ }^{10}$ The Reuther-Chavez Award, named for ADA cofounder and United Auto Workers president Walter Reuther and United Farm Workers leader Cesar Chavez, was created by the ADA "to recognize important activist, scholarly and journalistic contributions on behalf of workers' rights, especially the right to unionize and bargain collectively."

${ }^{11}$ Citation on file with Human Rights Watch.

${ }^{12}$ See Carl Swidorski, "From the Wagner Act to the Human Rights Watch Report: Labor and Freedom of Expression and Association, 1935-2000," 25 New Political Science 55 (March 2003).

${ }^{13}$ See Sheldon Friedman and Stephen Wood, eds., "Employers' Unfair Advantage in the United States of America: Symposium on the Human Rights Watch Report on the State of Workers' Freedom of Association in the United States, 39 British Journal of Industrial Relations 591 (December 2001) and 40 British Journal of Industrial Relations 114 (March 2002), with Hoyt N. Wheeler, "The Human Rights Watch Report from a Human Rights Perspective"; Julius Getman, "A Useful Step"; David Brody, "Labour Rights as Human Rights: A Reality Check"; Lance Compa, "Reply to Wheeler-Getman-Brody Papers"; Roy J. Adams, “The Wagner Act Model: A Toxic System beyond Repair"; Sheldon Leader, "Choosing an Interpretation of the Right to Freedom of Association"; K. D. Ewing, "Human Rights and Industrial Relations: Possibilities and Pitfalls."

${ }^{14}$ See James A. Gross, "Book Review: Unfair Advantage: Workers' Freedom of Association in the United States under International Human Rights Standards," 4 University of Pennsylvania Journal of Labor and Employment Law 699 (Spring 2002).

${ }^{15}$ See Blood, Sweat, and Fear: Workers' Rights in the U.S. Meat and Poultry Industry (2005).

${ }^{16}$ See Human Rights Watch, Discounting Rights: Wal-Mart's Violations of US Workers' Right to Freedom of Association (2007).

${ }^{17}$ For more information, see the Amnesty International USA website at http://www.amnestyusa.org; the Oxfam America website at http://www.oxfamamerica.org.

${ }^{18}$ See Steven Greenhouse, “Labor to Press for Workers' Right to Join Unions," The New York Times, December 9, 2005, at A18; Alison Grant, "Labor Supporters Take to Streets; Week of Demonstrations Meant to Rev up U.S. Union Movement," Cleveland Plain Dealer, December 10, 2005, at C2; Tracy Idell Hamilton, "Labor Union Advocates Rally for BetterWorkers' Rights," San Antonio Express-News, December 11, 2005, at 5B. 
${ }^{19}$ For more information, see http://www.aflcio.org/joinaunion/voiceatwork/efca/.

${ }^{20}$ See Senator Edward M. Kennedy, "Leveling the Playing Field for AmericanWorkers," LERA Perspectives on Work Online, Labor and Employment Relations Association, 2005.

${ }^{21}$ See the ARAW website at http://www.araw.org for detailed information on the group's program and activities.

${ }^{22}$ See the NESRI website at http://www.nesri.org.

${ }^{23}$ See the RFK Center website at http://www.rfkmemorial.org; the Coalition website at http://www.ciwonline.org.

${ }^{24}$ See, for example, Leslie D. Alexander, "Fashioning a New Approach: The Role of International Human Rights Law in Enforcing Rights of Women Garment Workers in Los Angeles," 10 Georgetown Journal of Poverty Law and Policy 81 (Winter 2003).

${ }^{25}$ See the NELP website at http://www.nelp.org.

${ }^{26}$ See the NWI website at http://www.workrights.org.

${ }^{27}$ See IWJ website at http://www.iwj.org.

${ }^{28}$ See, for example, Maya Bell, “UM's Low-Wage Workers to Get Pay Raise, Benefits,” Orlando Sentinel, March 18, 2006, at B5; Christ Nye, "Georgetown U. Hunger StrikersWinsWage Increase forWorkers," The Eagle (American University), April 1, 2005; Joel Currier, "WU Hunger Strike Followed Similar Campus Protests Nationwide; The Students' Action at Washington University Grabbed the attention of National Labor Group," St. Louis Post-Dispatch, April 17, 2005, at D3; Robert A. Frahm, "StudentsOccupy UConn Office; Janitors' Wage Issue Spurs Return to Tactic of Yesteryear," Hartford Courant, May 10, 2001, at A3.

${ }^{29}$ See International Brotherhood of Teamsters, "Workers' Rights Violations atMaersk: Report and Analysis; Actions by U.S. Divisions of Maersk Corporation in Light of International Human Rights and Labor Rights Standards," June 1, 2004.

${ }^{30}$ See Bill Mongelluzzo, “Teamsters Shift Gears: Union Targets Maersk Sealand in Campaign to Organize Port Drivers," Journal of Commerce, September 13, 2004, at 13; Rajesh Joshi and Andrew Draper, "Maersk Target of Protest by Thousands of Truckers: Company Accused of 'Threatening, Intimidating and Terminating Drivers,' " Lloyd's List, September 6, 2004, at 3; "Mærsk ramt af strejke i USA: Mærsk undertrykker og nægter at anerkende fundamentale rettigheder for transportarbejdere, som nu har besluttet at tage strejkevåbenet i brug i havnene Miami og San Francisco," Netavisen APK, August 2004.

${ }^{31}$ See Bill Mongelluzzo, "Teamsters Pushes Maersk Driver Protest; Union Hits Carrier's Shareholders Meeting," Journal of Commerce Online, April 19, 2005.

${ }^{32}$ Id., "Teamsters Want Maersk to Abide by UN Workers Rules," April 11, 2006.

${ }^{33}$ See AFSCME, "Freedom of Association and Workers' Rights Violations at Resurrection Health Care: Report and Analysis under International Human Rights and Labor Rights Standards," Prepared for Worker Rights Board Hearing, Chicago, Illinois, August 26, 2004.

${ }^{34}$ See, for example, "Catholic Scholars Call for Hospital Chain to Respect Workers' Rights; Open Letter Cites Resurrection Health Care's Intimidation of Employees," PR Newswire, December 14, 2006.

${ }^{35}$ See Barrie Clement, "First Group to Stamp out US Union Bashing," The Independent (London), July 14, 2006 , at 54.

${ }^{36}$ See AFL-CIO, "Complaint Presented by the AFL-CIO to the ILO Freedom of Association Committee," October 2002.

${ }^{37}$ See ILO Committee on Freedom of Association, Complaint against the United States, Case No. 2227, Report No. 332 (2003). 
${ }^{38}$ See Oakwood Healthcare, Inc., 348 NLRB No. 37; Croft Metal, Inc., 348 NLRB No. 38; Golden Crest Healthcare Center, 348 NLRB No. 39 (October 2, 2006), called the Oakwood trilogy.

${ }^{39}$ See Pakistan (Case No. 1534), Dominican Republic (Case No. 1751), Pakistan (Case No. 1771), Peru (Case No. 1878), Canada (Case No. 1951).

${ }^{40}$ See International Commission for Labor Rights, "The Denial of Public Sector Collective Bargaining Rights in the State of North Carolina (USA): Assessment and Report," June 14, 2006. See the website of the ICLR at http://www.labourcommission.org/.

${ }^{41}$ See ILO Committee on Freedom of Association, Complaint against the United States, Case No. 2460, Report No. 344 (2007).

${ }^{42}$ See information on these complaints at the UE website, http://www.ranknfile-ue.org/.

${ }^{43}$ See AFL-CIO, Complaint to the ILO Committee on Freedom of Association by the American Federation of Labor and Congress of Industrial Organizations concerning the United States Government's Violations of Freedom of Association and Collective Bargaining by Failing to Enforce the National Labor Relations Act, October 25, 2007; see also David Moberg, "Labor Strikes Back: The AFL-ClO Has Filed a Formal Complaint with the International Labor Organization over the State of Labor Law in the United States. How Have Things Gotten So Bad?" The American Prospect (web version), November 1, 2007.

${ }^{44}$ See Dana Corp., 351 NLRB No. 28 (September 29, 2007).

45 Joseph McCartin, “Democratizing the Demand for Workers' Rights: Toward a Re-Framing of Labor's Argument," Dissent (Winter 2005).

${ }^{46}$ Nelson Lichtenstein, “The Rights Revolution," New Labor Forum (Spring 2003).

${ }^{47}$ David Brody, "Labor Rights as Human Rights: A Reality Check," British Journal of Industrial Relations (December 2001).

${ }^{48}$ NLRB v. Mackay Radio \& Telegraph Co., 304 U.S. 333 (1938); First National Maintenance Corp. v. NLRB, 452 U.S. 666 (1981); Lechmere, Inc. v. NLRB, 502 U.S. 527 (1992); NLRB v. Kentucky River Community Care, Inc., 532 U.S. 706 (2001); Oakwood Healthcare, Inc., 348 NLRB No. 37; Hoffman Plastic Compounds, Inc., v. NLRB, 535 U.S. 137 (2002); Dana Corp., 351 NLRB No. 28 (September 29, 2007).

${ }^{49}$ NLRB v. Jones \& Laughlin Steel Corp., 301 U.S. 1 (1937). 